\title{
Rock outcrop habitats in the Venezuelan Guayana lowlands: their main vegetation types and floristic components
}

\author{
ANDREAS GRÖGER ${ }^{1,4}$ and OTTO HUBER ${ }^{2,3}$
}

(received: November 12, 2004; accepted: July 10, 2007)

\begin{abstract}
Rock outcrop habitats in the Venezuelan Guayana lowlands: their main vegetation types and floristic components). The Guayana Shield, located in north-eastern South America, consists of a highly complex and composite mosaic of landscape elements. Amongst these, inselbergs are very conspicuous, because of their peculiar shape and their unusual associated vegetation. Geologically, these rock outcrops are part of the underlying ancient igneous-metamorphic basement and occur mainly in the lowlands of the periphery of the shield. As azonal habitats, inselbergs harbour a highly specialized flora. The characteristic vegetation is composed of lithophytic and savanna-like plant communities, as well as low dry forests. As a whole, the vegetation of an inselberg may be interpreted as a mosaic of marginal habitats. Therefore a large number of taxa find suitable niches in a quite condensed space. Gradients of soil depth and water availability are the main factors determining the floristic composition. A preliminary floristic inventory of the Venezuelan inselberg flora comprises 614 vascular plant species. $24 \%$ of them are endemic to the Guayana region, $15 \%$ are endemic to inselbergs of the Guayana region. The distribution patterns of these latter, eco-endemic species allows to distinguish a northern and a southern inselberg district. The two districts overlap in the Átures area, in the surroundings of Puerto Ayacucho, where a true centre of endemism is located. The distinction into two districts is emphasised by different phytogeographic relations. The southern inselberg district shows connections to the "tepui" flora, whereas the northern district reveals phytogeographic relations to the Caribbean region as well as to the Brazilian Shield. Possible explanations for the floristic interchange across the equator are discussed.
\end{abstract}

Key words - endemism, flora, Guayana Shield, inselberg, phytogeography, Venezuela

RESUMO - (Hábitats em afloramentos rochosos nas terras baixas da Guiana Venezuelana: os principais tipos vegetacionais e componentes florísticos). O Escudo das Guianas, situado no nordeste da América do Sul, consiste de um mosaico altamente complexo de elementos de paisagem. Dentre estes, os "inselbergs" são particularmente conspícuos, pelo seu formato peculiar e a incomum vegetação associada. Geologicamente, estes afloramentos rochosos são parte de um antigo substrato ígneometamórfico e ocorrem principalmente nas terras baixas da periferia do escudo. Como hábitats azonais, os "inselbergs" abrigam uma flora altamente especializada. A vegetação característica é composta de comunidades litofíticas, semelhantes a savanas, bem como de florestas secas baixas. Como um todo, a vegetação de um "inselberg" pode ser vista como um mosaico de hábitats marginais. Assim, um grande número de táxons encontra nichos adequados em um espaço extremamente condensado. Gradientes de profundidade de solo e disponibilidade de água são os principais fatores determinando a composição florística. Um inventário florístico preliminar da flora de “inselbergs" venezuelanos inclui 614 espécies de plantas vasculares. Destas, $24 \%$ são endêmicas à região das Guianas, e $15 \%$ são endêmicas aos "inselbergs" da região das Guianas. O padrão de distribuição destas últimas espécies "eco-endêmicas" permite distinguir um distrito norte e o outro sul para os "inselbergs". Os dois distritos se sobrepõem na área de Átures, nos arredores de Puerto Ayacucho, onde se encontra um verdadeiro centro de endemismos. A distinção entre dois distritos é enfatizada pelas diferentes relações fitogeográficas. O distrito sul apresenta conexões florísticas com a flora do "tepui", enquanto que o distrito norte revela elos fitogeográficos com o Caribe e com o Escudo Brasileiro. São discutidas possíveis explicações para o intercâmbio florístico através do Equador.

Palavras-chave - endemismo, Escudo das Guianas, fitogeografia, flora, “inselberg”, Venezuela

\section{Introduction}

The Guayana Shield is located in northern South America, approximately between $0^{\circ}$ and $6^{\circ}$ lat $\mathrm{N}$ and $50^{\circ}$ to $72^{\circ}$ long $\mathrm{W}$. This area of more than 1 million square

1. Botanischer Garten München-Nymphenburg, Menzinger Str. 65, D80638, München, Germany

2. CoroLab Humboldt, CIET/IVIC, Apartado 21827, Caracas 1020A, Venezuela

3. Present address: Fundación Instituto Botánico de Venezuela, Apartado 2156, Caracas 1010-A, Venezuela

4._Corresponding author: a.groeger@extern.lrz-muenchen.de kilometers is limited to the North by the Orinoco river, to the East by the Atlantic Ocean and to the South roughly by the middle and lower course of the Amazon river. In the West it reaches into the Colombian Amazonia as far West as the Chiribiquete mountains and the Araracuara rapids on the Caquetá river. It is characterized by the large mountain system of the Guayana Highlands which form the watershed between the Amazon and the Orinoco rivers. Elevations of the numerous, typically flat-topped mountains range between a few hundred meters in the surrounding piedmont peneplains to more than $3,000 \mathrm{~m}$. 
The area occupied by the Guayana Shield includes a wide range of lowland, upland and highland ecosystems and is furthermore considered to be one of the oldest continental nuclei of South America. For these reasons, an unusually high biotic and landscape diversity has been discovered there during the past 200 years, leading to the establishment of a particular biogeographical entity, the Guayana Region (Maguire 1979, Huber 1994, Berry et al. 1995).

One of the outstanding biomes of this region are the numerous granitic outcrops, called "lajas" by the local Spanish speaking people: these consist of huge, dark black, rocky boulders and hills with a characteristically dome-like appearance, seldomly more than 300-400 m high, but of a very variable horizontal extension ranging between a few square meters up to several square kilometers. Humboldt and Bonpland in April 1800 were certainly not the first to see these strange formations, when they entered the upper Orinoco region, but they were surely the first naturalists astonished by such an impressive landscape feature, and especially by the highly specialized flora with its many endemic species found growing there. Since then, only little research has been focused towards these ecosystems, but in recent years some detailed studies have been made in the Venezuelan Guayana, unraveling an intricate, highly complex mosaic of plant communities and niches living under almost prohibitive environmental conditions.

\section{Northwestern Guayana Shield}

Geology - The geology of the northwestern Guayana Shield is rather complex, partly because large areas of it are still not sufficiently well explored or understood. Generally speaking, however, three main lithological units can be recognized (Mendoza 1977, Huber 1995a). (1) An igneous-metamorphic basement consisting principally of granites and granitoid gneisses; this Precambric nucleus, dating back as far as 2,500 million years or more, represents the early landmass which had formed, together with the southernly adjacent Brazilian Shield, the primeval continents of Pangaea.

(2) A huge, extensive sedimentary cover, made up of Precambrian quartzites and sandstones; probably during more than 1,000 million years the basement of the Guayana Shield had been covered, intermittently and in phases of variable intensity and extension, by innumerable layers of sand which eventually reached the thickness of eight kilometers. Once this huge sedimentary cover was exposed to intensive tectonic and weathering processes, it became fragmented into several blocks, separated by continuously growing river valleys. Today some 50 more or less isolated table mountains of up to 3,000 m elevation are impressive remnants of that once continuous, mighty cover of sandstones.

(3) Younger intrusive rocks (mainly ultramafic diabases), which penetrated the basement and sedimentary cover during repeated volcanic episodes of the Paleozoic and Mesozoic.

Although the sandstones and quartzites of the Roraima Group today only occupy a relatively small area of the Guayana Shield, their widely visible, impacting broad table mountains emerging from the forests into the sky with their massive walls, surely represent the largest and most varied open rock surfaces of the region. On the other hand, the igneous-metamorphic basement of the Guayana Shield covers much less surface, because it only appears in the form of many isolated inselbergs in the lowlands and in a few higher mountain ranges and plateaus. The intrusive rocks (diabases) are hardly visible on the surface, due to dense forest cover.

Geomorphology - The gradual erosion of the sedimentary cover of the Guayana Shield has produced an essentially horizontally structured landscape, where a series of level or slightly inclined plains descend stepwise from the high plains on the summit of the flat table mountains, to terraced slopes with narrow upland plains or larger upland plateaus, and finally lead to the very large, extensive plains and peneplains of the surrounding lowlands. Thus, the Guayanan landscape consists of a highly complex and composite mosaic of terrain forms, where open rock surfaces are commonly found in the following geomorphological units: a) lowland peneplains and plains, where they appear as true inselbergs ("lajas"), at elevations of 50-600 m a.s.l.; they are part of the Precambrian basement and consist of igneous-metamorphic rock types, mainly granites and granitoid gneisses; b) upland and highland plateaus and summits of the flat-topped sandstone mountains ("tepuis"), at elevations of 1,500-3,000 m a.s.1.; "tepuis" are remnants of an extensive layer of sedimentary rock, mainly quartzite and sandstone; c) upland and highland plateaus and mountains of granitic ranges, such as the Sierra Maigualida, Sierra Parima and part of the Sipapo Massif, at elevations of 1,000-2,400 m a.s.l.

In the present paper, however, only lowland rock outcrops (inselbergs, "lajas") of the northwestern border of the Guayana Shield in Venezuela will be discussed, because the high mountain rock vegetation is still poorly explored.

Macroclimate-The inselbergs of the Venezuelan Guayana are situated in the lowlands within two climatic zones (Huber 1995a). Towards the north within a macrothermic 
tropophilous climate (hot and moderately dry), which features a mean annual temperature of $>24{ }^{\circ} \mathrm{C}$, a mean annual rainfall of 1,000-2,000 mm, and 2-5 dry months per year. Towards the south within a macrothermic ombrophilous climate (hot and wet), which features a mean annual temperature of $>24^{\circ} \mathrm{C}$, a mean annual rainfall of $>2,000 \mathrm{~mm}$, and less than 2 dry months per year.

There is a gradient of rainfall amount and duration from North to South. Therefore, inselbergs located in northwestern Amazonas State until approx. Puerto Ayacucho $\left(5^{\circ}\right.$ lat $\left.\mathrm{N}\right)$, are subject to a rather severe dry season lasting from December to March/April, with very low levels of precipitation $(<50 \mathrm{~mm} /$ month). As a consequence, the phenological aspect of the saxicolous vegetation during that period is characterized by many deciduous shrubs and low trees with showy flowers, whereas the herbaceous layer growing in the low depressions dries out, except for succulent species like cacti, terrestrial bromeliads and orchids.

Further to the south, between $5^{\circ}$ and $2^{\circ}$ lat $\mathrm{N}$, the rainfall regime changes markedly and the ecologically dry period of the year is reduced to less than two months, at the beginning of the year. There, the saxicolous vegetation contains only a few deciduous species and the dominant shrubs have a coriaceous, evergreen foliage.

\section{Granitic outcrops}

Location and geomorphology - Granitic inselbergs are scattered all over the lowlands of the Guayana Region, but are concentrated along the periphery of the Shield, especially in the northwestern (Venezuelan-Colombian) and south-eastern (Suriname-French Guiana-Brazilian) sections, where many, more or less isolated granitic hills rise above the generally level forest or savanna landscape (figure 1). In some of these areas, inselbergs are so numerous, that they may cover $15 \%$ of the land surface

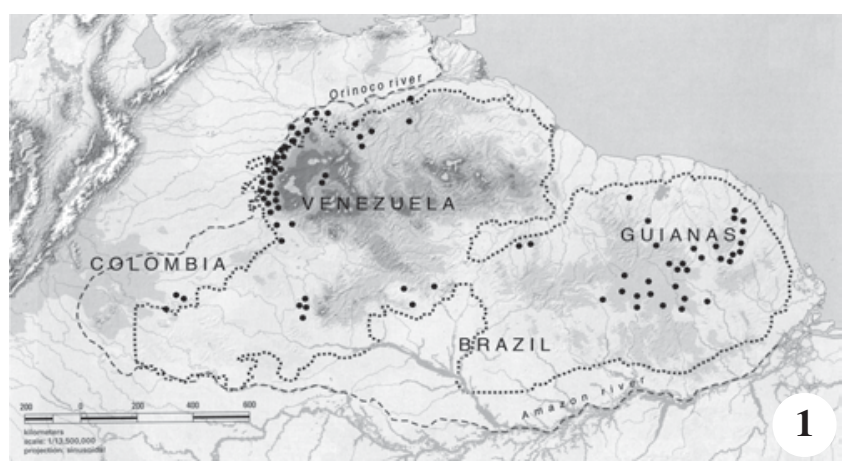

Figure 1. Granitic rock outcrops in the Guayana Shield (base map taken from Huber \& Foster 2003). (e.g., in the Átures area around Puerto Ayacucho, Venezuela, compare Gröger \& Barthlott 1996).

Invariably, these rock outcrops belong to the igneousmetamorphic basement of the Guayana Shield and are made up of a coarse-grained granitic rock type with large crystals of feldspate or of granitoid gneisses, typically belonging to the regional "Parguaza" granitic batholith. Their form is mostly that of rounded boulders (sugar loaf) with moderately to steeply inclined slopes. In some cases, the rock surface presents pseudocarstic erosion phenomena, such as vertical channeling, typical of "Rapakivi" granite (Blancaneaux \& Pouyllau 1977) and formation of concentric depressions (pans). These rocky hills, usually between 50 and $300 \mathrm{~m}$ high, appear either isolated in the forest or savanna, or they form compound massifs, often reaching several kilometers of extension (figure 2). Their black color is the result of a dense cover of microorganisms (see below), and not of crusts of manganese as originally assumed by Humboldt (1819).

As a result of the increased attention of botanists and ecologist to these outstanding tropical lowland habitat in Venezuelan Guayana, several, particularly scenic and biologically diverse "lajas" have been legally protected through their inclusion in the conservation category "Monumento Natural". These are "Piedra La Tortuga" (Gröger 1994) and "Piedra Pintada", both located in the southern vicinity of Puerto Ayacucho, and "Piedra Cocuy", on the border between Venezuela, Brazil and Colombia. Their protection as natural monuments is not only justified by their biological importance, but also because these rock outcrops often represent important cultural sites for the indigenous inhabitants: "Piedra La Tortuga" is famous since Humboldt's visit in April 1800, when he studied the remnants of an ancient indigenous cemetery; "Piedra Pintada" has impressive, giant PreColombian stone carvings on a steep, inaccessible slope (figure 3).

Microclimate - Granitic outcrops feature very specific microclimatic conditions. Measurements with an air temperature and humidity data logger, conducted during the dry season in the vicinity of Puerto Ayacucho (Gröger 1994, 1995), revealed the following microclimatic scenario on inselbergs. One meter above the bare rock surface, as well as $0.2 \mathrm{~m}$ above low herbaceous vegetation, temperatures exceeded $40{ }^{\circ} \mathrm{C}$ at 11 a.m., and reached a maximum of $45^{\circ} \mathrm{C}$ between 2 and 3 p.m. At about 5 p.m. temperature dropped below $40^{\circ} \mathrm{C}$. After sunset it declined gradually, but normally not falling below $25{ }^{\circ} \mathrm{C}$. Air humidity behaved in the opposite manner, with a maximum in the early morning of $75 \%$, and a minimum of $20 \%$ between 2 and 3 p.m. Due to generally very shallow 

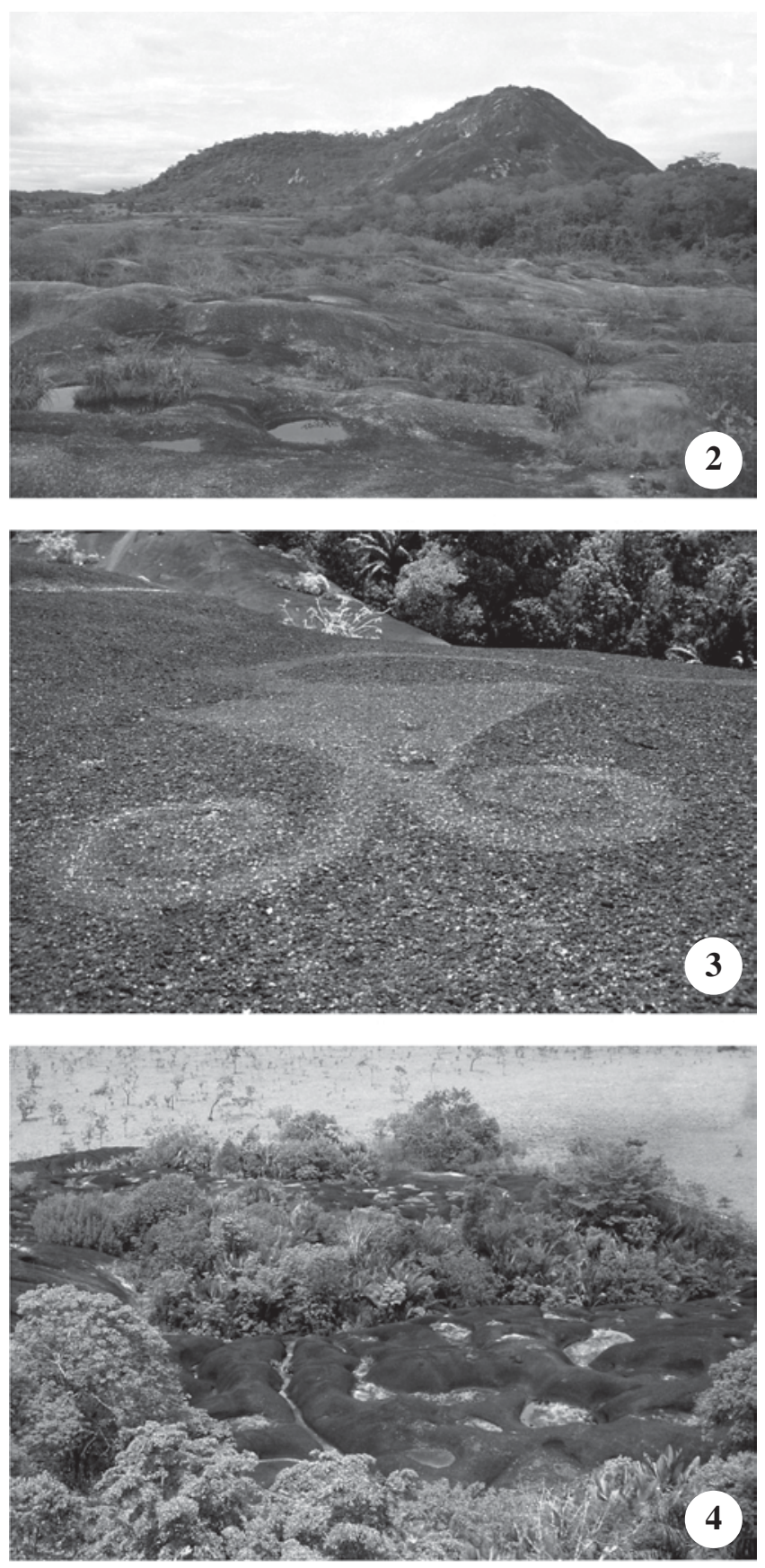

Figure 2-4. Inselberg "Piedra La Tortuga", in the vicinity of Puerto Ayacucho. Figure 3. Pre-Colombian stone carvings on "Piedra Pintada", in the vicinity of Puerto Ayacucho. Figure 4. Vegetation mosaic on an inselberg in the Átures area.

soils and their low water retaining capacity, hydrologic conditions on inselbergs are quite harsh. Even a short dry period of only a few weeks leads to severe stress for the inselberg vegetation. Intermittent water availability is one of the main limiting factors for the vegetation on inselbergs. Inselbergs in the humid tropics thus represent edaphic as well as microclimatic xeric islands, surrounded by areas with a more favourable water supply.
Vegetation - The vegetation found on granitic outcrops is characteristically adapted to the rocky substrate (saxicolous or lithophytic lifestyle, Huber 1995b). Sometimes it is circumscribed as savanna-like ("savaneroche" in French Guyana, compare De Granville 1991), but inselberg vegetation is much more complex on a smaller scale than any savanna vegetation type. Different modes of sculpturing of the rock surface produce a large variety of differently sized depressions, gullies, channels, cracks and boulders, each with different amounts and quality of soil, each with a different water supply, thereby creating a considerable variety of habitats (figure 4).

The typical vegetation cover of inselbergs is discontinuous, separated by open rock, and composed of different vegetation units. The following main vegetation types can be recognized on inselbergs: lithophytic vegetation; xerophytic, savanna-like vegetation; low, 2$8 \mathrm{~m}$ tall, seasonally dry forest or woodland; and tall, evergreen forest.

Inselberg vegetation is determined by a complex system of gradients, mainly soil depth and water availability. Therefore it is difficult to define a larger patch of really homogeneous vegetation cover. Especially its low vegetation may be interpreted as a network of marginal habitats. Like vegetation fringes in general, they offer suitable niches for a large number of species. This condensation effect of marginal habitats, concentrating species in a smallscaled ecotone, is one of the most important aspects for considerations on floristic diversity of inselbergs. Keeping this merging in mind, the main vegetation types can be circumscribed as follows:

(1) Lithophytic vegetation - Bare rock is covered nearly completely by lichens or cyanobacteria. In drier regions like the northern margin of Bolívar State, lichens (Peltula spp.) prevail. In regions, where annual rainfall exceeds $1,500 \mathrm{~mm}$, blue-green algae [e.g. Gloeocapsa sanguinea (Ag.) Kütz., Chroococcidiopsis sp., Stigonema mamillosum (Lyngb.) Ag.] dominate (Büdel et al. 1994). Only very few vascular plants are able to colonize the bare rock surface, e.g. bromeliads like Tillandsiaflexuosa Sw. and T. schiedeana Steud., or orchids such as Encyclia leucantha Schltr. and Pleurothallis granitica Luer \& G.A. Romero.

(2) Savanna-like vegetation - A restricted set of pioneer species is adapted to grow in small rock depressions with a scarce accumulation of debris. According to their water regime, the life forms of these pioneer communities can be very different. Only stem succulents (e.g. Melocactus spp.), leaf succulents (e.g. Pitcairnia spp., Portulaca sedifolia N.E. Br.) or tiny geophytes (e.g. Portulaca pygmaea Steyerm.) can withstand extreme fluctuations 
in water supply. If the water supply is somewhat more regular, Cyperaceae (Bulbostylis spp., Rhynchospora spp.), Poaceae (Axonopus spp., Ischaemum spp.) and Xyridaceae (Xyris spp.) may be able to establish meadowlike communities. Deepened rock holes with seasonal pools may harbour aquatic (e.g. Bacopa callitrichoides (Kunth) Pennell, Utricularia spp.) and semi-aquatic ephemerals (e.g. Bulbostylis aturensis (Maury) C.B. Clarke, Eriocaulon spp.). But the most typical vegetation units, that establish in rock depressions, are mats of bromeliads. Several species of Pitcairnia - subgenus Pepinia (Pitcairnia armata Maury, P. bulbosa L.B. Sm. and $P$. pruinosa Kunth) are important key species for the further succession on Guayanan inselbergs. In the first stage of colonization they may be associated with Bulbostylis leucostachya (Kunth) C.B. Clarke and Vellozia tubiflora (A. Rich.) Kunth (Bulbostylis leucostachya exclusively with P. armata and P. pruinosa; Vellozia tubiflora exclusively with $P$. bulbosa). Only if the colonies of Pitcairnia reach a certain size, and sufficient organic material accumulates underneath their mats, the first seedlings of woody species will establish (figure 5). Later successional stages lead to the typical shrub islands with Acanthella spp., Clusia spp., Diacidia galphimioides Griseb., Erythroxylum spp., Tabebuia orinocensis (Sandwith) A.H. Gentry etc., which contribute considerably to the floristic diversity of inselberg vegetation.

(3) Low dry forest - In larger rock depressions and on the flat top of inselbergs, comparatively species-poor, low, dry forests can be found. Dominant tree species belong to the Clusiaceae (Clusia spp.), Myrtaceae (e.g. Calyptranthes spp., Eugenia spp., Myrcia spp.) and Arecaceae (e.g. Attalea spp., Syagrus orinocensis (Spruce) Burret, figure 6A). Other important tree families are Rubiaceae (e.g. Simira spp., Isertia spp.), Bombacaceae (Pachira spp.), Bixaceae (Cochlospermum spp.) and Bignoniaceae (e.g. Tabebuia spp., Jacaranda spp.). On the forest floor, vegetation varies according to parameters, such as light, soil, moisture, root competition, etc. It may consist of scattered individuals of Zamia lecointei Ducke, closed carpets of Chrysothemis dichroa Leeuwenb., spiny populations of Ananas parguazensis Camargo \& L.B. Smith, etc. Diverse in species are the margins of the low dry forests (figure 6B), which share a lot of species with the shrub patches of small depressions, but are especially rich in lianas, like Mandevilla spp., Abuta imene (Mart.) Eichler, Davilla kunthii A. St.-Hil. and Dioclea guianensis Benth. A typical liana growing within the low Clusia-forests, is Souroubea guianensis Aubl. (4) Low to medium evergreen forest - Evergreen forests with heights regularly exceeding $6 \mathrm{~m}$, may also occur on
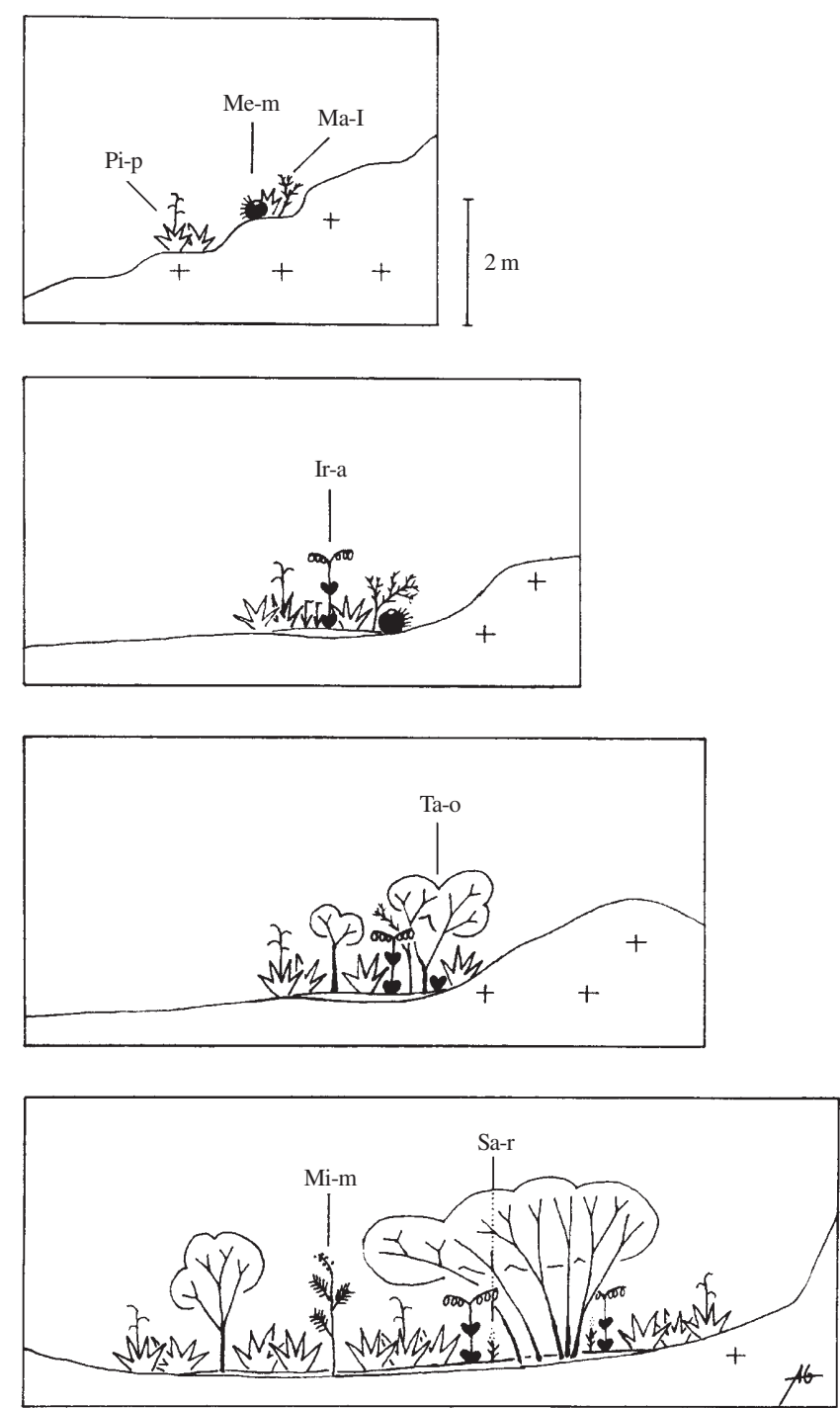

Figure 5. Establishment of woody species in depressions (Átures area). (Ir-a $=$ Chelonanthus alatus (Aubl.) Pulle; Ma-1 = Mandevilla lancifolia Woodson; Me-m $=$ Melocactus mazelianus Ríha; Mi-m = Mimosa microcephala Humb. \& Bonpl. ex Willd.; Pi-p = Pitcairnia pruinosa Kunth; Sa-r = Sauvagesia ramosissima Spruce ex Eichler; Ta-o = Tabebuia orinocensis (Sandwith) A.H. Gentry).

inselbergs. They need a deep soil layer, found in very large rock depressions or cracks, or also among boulders on top of the inselbergs. The floristic inventory of these forests was excluded from this study, because it is mainly a repetition of the evergreen forests of the Guayana Shield. Not excluded are the margins of these forests and the boulders within them. The margins share most of the species with the low dry forests, adding some characteristic shrubs and trees like Byrsonima nitidissima Kunth, Tabebuia pilosa A.H. Gentry, etc. The boulders within the forests are frequently covered with shade tolerant lithophytes, like Peperomia maypurensis Kunth, Vriesea bibeatricis Morillo, etc. 


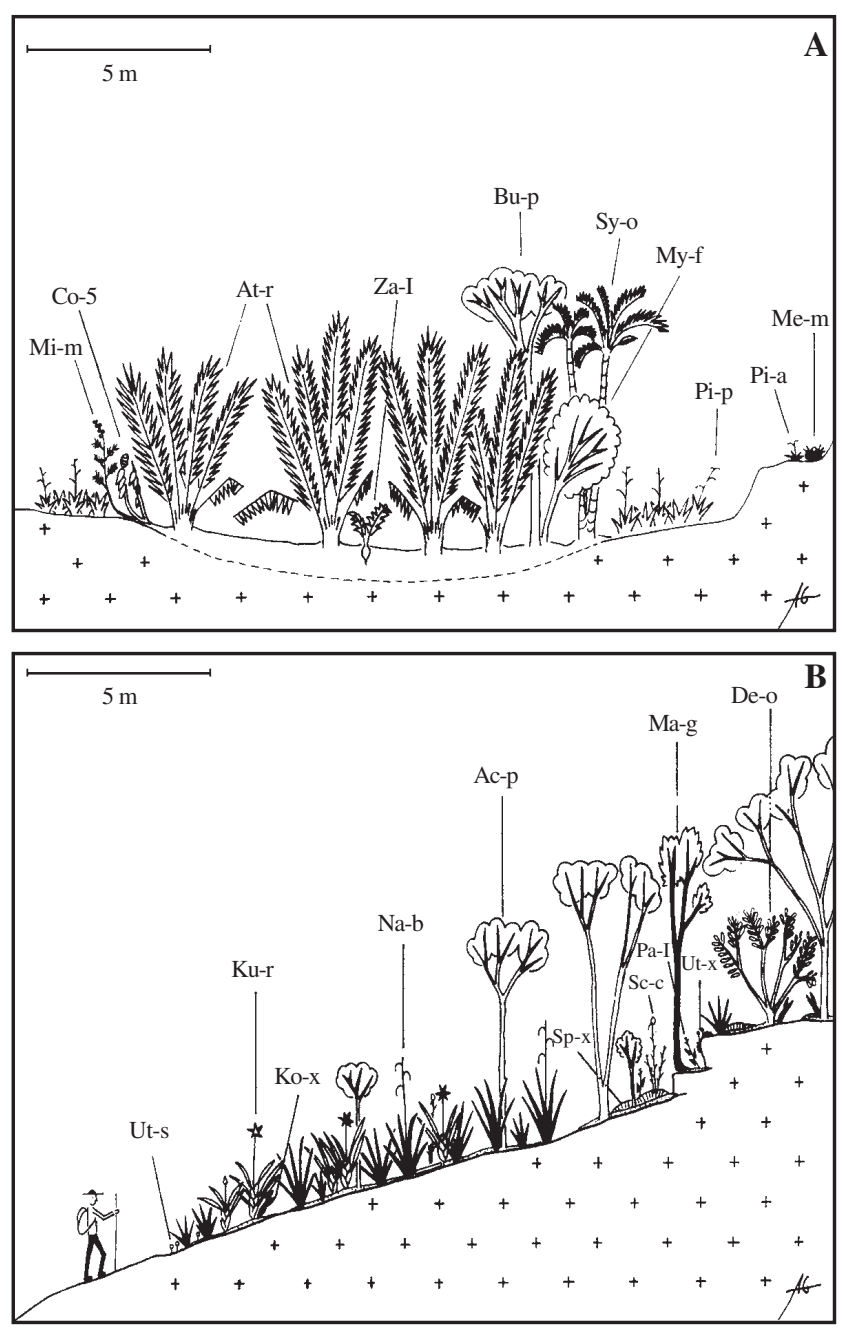

Figure 6. A. Palm dominated dry forest (Átures area). (At-r = Attalea racemosa Spruce; Bu-p = Buchenavia parvifolia Ducke; Co-s $=$ Costus spiralis (Jacq.) Roscoe; Me-m = Melocactus mazelianus; $\mathrm{Mi}-\mathrm{m}=$ Mimosa microcephala $; \mathrm{Pi}-\mathrm{a}=$ Pitcairnia armata Maury; Pi-p = Pitcairnia pruinosa $;$ Sy-o = Syagrus orinocensis (Spruce) Burret; Za-l = Zamia lecointei Ducke. B. Forest margin on granitic outcrop (Sipapo area). Ac-p = Acanthella pulchra Gleason; De-o = Decagonocarpus oppositifolius Spruce ex Engl.; Ko-x = Koellensteinia sp.; $\mathrm{Ku}-\mathrm{r}=$ Kunhardtia radiata Maguire \& Steyerm.; Ma-g = Macrolobium gracile Spruce ex Benth.; Na-b = Brewcaria brocchinioides (L.B. Sm.) B. Holst; Pa-1 = Parodiolyra luetzelburgii (Pilger) Soderstr. \& Zuloaga; Sc-c $=$ Scleria cyperina Kunth; $\mathrm{Sp}-\mathrm{x}=$ Sphagnum $\mathrm{sp}$.; Ut-s = Utricularia subulata $\mathrm{L}$.; Ut-x = Utricularia $\mathrm{sp}$ ).

Flora-A preliminary inventory of the Venezuelan inselberg flora comprises 614 species of vascular plants from 107 different families (Gröger 1995). This inventory relates only to the typical inselberg vegetation, i.e. it excludes tall evergreen forests on inselbergs. The most diverse families are Cyperaceae (40 spp.), Rubiaceae (40 spp.), Melastomataceae (36 spp.), Orchidaceae (33 spp.), Poaceae
(31 spp.), Bromeliaceae (20 spp.), Apocynaceae (18 spp.), Caesalpiniaceae (18 spp.), and Fabaceae (17 spp.).

On generic level, the taxa richest in species are Rhynchospora (17 spp.), Mimosa (9 spp.), Erythroxylum (8 spp.), Miconia (8 spp.), Bulbostylis (7 spp.), Eugenia (7 spp.), Mandevilla (7 spp.), Portulaca (7 spp.), Selaginella (7 spp.), Chamaecrista (6 spp.), Clidemia (6 spp.), Pitcairnia (6 spp.), Tabebuia (6 spp.) and Xyris (6 spp.).

Compared to other Guayanan lowland habitats (e.g., Boom 1990), granitic outcrops harbour a considerable number of endemic species. 144 species (24\%) of the flora recorded on Venezuelan inselbergs are endemic to the Guayana region. Fifty eight species (10\%) are reported exclusively for this type of ecosystem. Another 31 species (5\%) mainly occur on granitic outcrops with only a few reports from other ecologically similar sites in the Guayana region (e.g., rocky savanna; sandstone outcrops in lowland areas). Altogether 89 species (15\%) may be regarded as eco-endemic to inselbergs of the Guayana region. The majority of these species belongs to the families of Bromeliaceae, Apocynaceae, Cyperaceae and Melastomataceae.

The distribution of inselberg-endemics in Venezuela is not equal. An obvious centre of endemism is the Átures area, located in the northwestern corner of Amazonas State and adjacent Bolívar State. Within this area two different distribution patterns seem to overlap. One set of inselberg-endemic species is distributed from there to the north (northern inselberg district), another from there to the south (southern inselberg district). Additionally, some species are reported exclusively for the Átures centre of endemism, others occur in both districts. Very obvious examples for these different patterns are given by taxa, which comprise several inselberg-endemic species, like Pitcairnia (subgen. Pepinia) or Mandevilla (M. anceps Woodson, figure 7E; M. caurensis Markgr., figure 7A; M. filifolia Monach., figure 7B; M. lancifolia Woodson, figure 7C; $M$. steyermarkii Woodson, figure 7D).

Regarding life forms, the predominance of shrubs and small trees is one of the outstanding features of the Venezuelan inselberg flora and vegetation. More than $40 \%$ of the recorded flora are phanerophytes. They contribute also considerably to the portion of inselberg-endemic species. Thirty seven shrub and tree species are ecologically bound to this type of habitat.

Examples for deciduous shrub species, characterizing mainly the Átures centre of endemism and the drier northern inselberg district, are: a) Erythroxylum williamsii Standl. ex Plowman (figure 8A) - with its short-shoot growth habit and its small, obovate leaves, is the most distinct of three Erythroxylum species, endemic to Venezuelan 

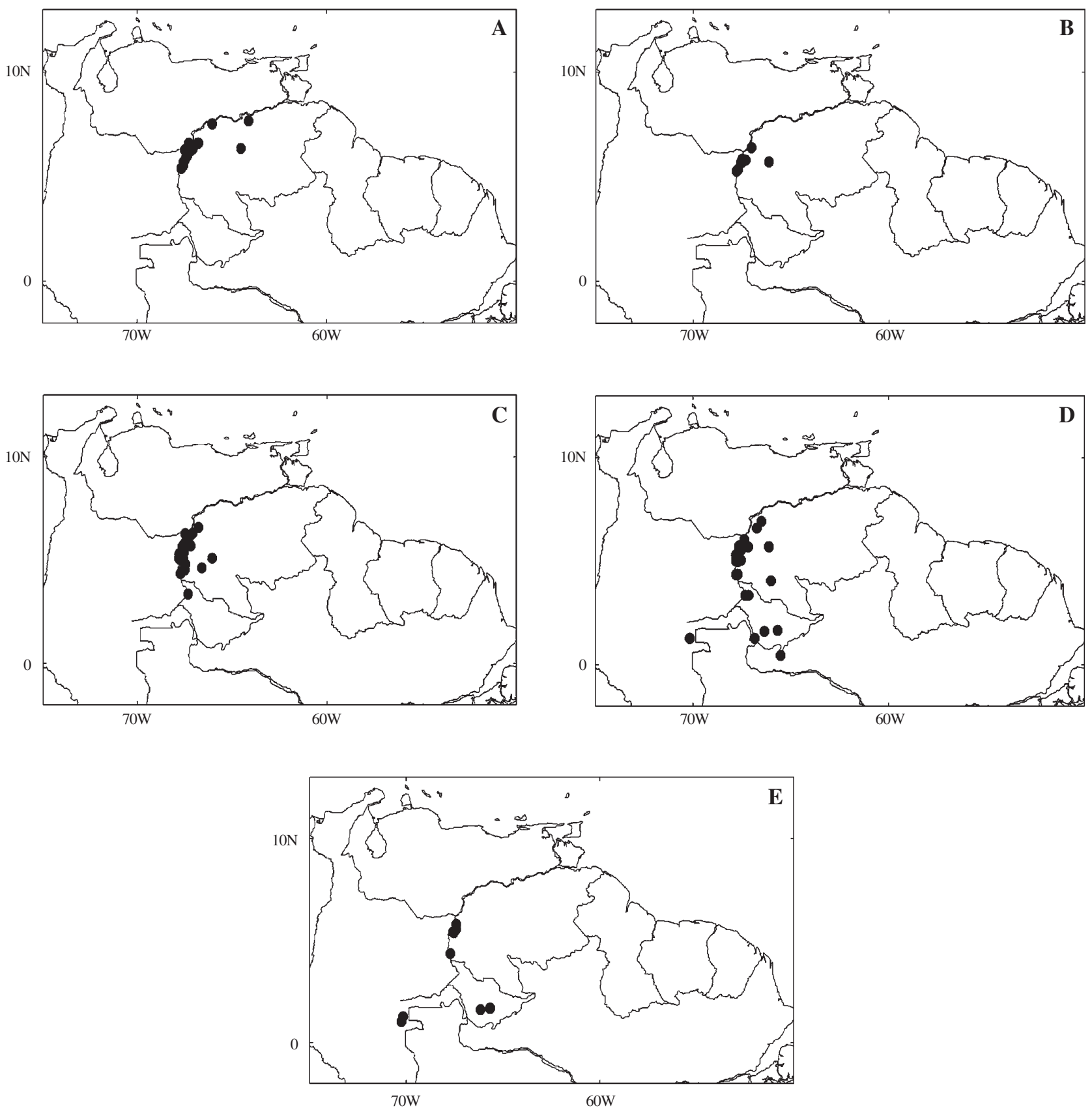

Figure 7. Examples for distribution patterns of inselberg-endemic species within one genus. A. Mandevilla caurensis Markgr. B. Mandevilla filifolia Monach. C. Mandevilla lancifolia Woodson. D. Mandevilla steyermarkii Woodson. E. Mandevilla anceps Woodson.

inselbergs; b) Pseudobombax croizatii A. Robyns (figure $8 \mathrm{~B}$ ) - one of the various pachycaulous species on inselbergs; the bottle-shaped stems are especially pronounced in juvenile plants, which root in very shallow soil pockets underneath rock scales (Gröger 2000); c) Tabebuia orinocensis (figure 8C) - adapted to the habitat of rock depressions, reaching a maximum height of $3 \mathrm{~m}$; its next relatives are 10-35 m high trees.

Within the southern inselberg district, which reaches into adjacent Colombia, most of the inselberg-endemic shrubs are evergreen, such as: a) Decagonocarpus oppositifolius Spruce ex Engl. (figure 9A) - an extraordinary Rutaceae that forms Clusia-like thickets in seepage areas; b) Diacidia galphimioides (figure 9B) - it dominates shrub islands, where it is very conspicuous by its straight erect, flowering shoots.

But even in the perhumid southern inselberg district, very short periods without precipitation may have a severe impact on plant species. For that reason, the distribution range of some deciduous inselberg-endemic species reaches 

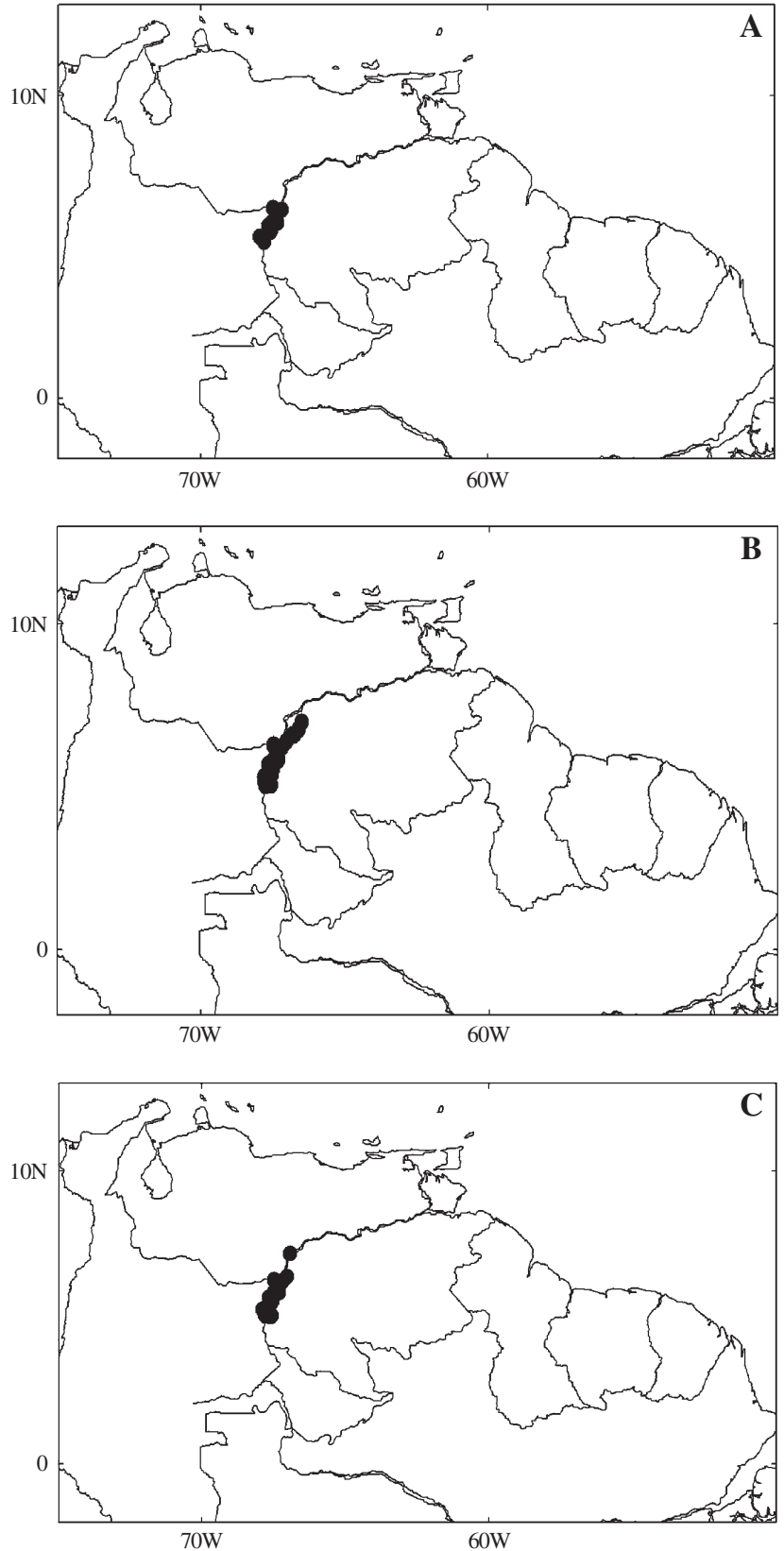

Figure 8. Distribution maps of some deciduous shrub species, endemic to the northern inselberg district. A. Erythroxylum williamsii Standl. ex Plowman. B. Pseudobombax croizatii A. Robyns. C. Tabebuia orinocensis (Sandwith) A.H. Gentry.

far to the south (e.g. Acanthella sprucei Hook. f., figure 9C, Gröger \& Renner 1997).

Phytogeographic relations - Granitic outcrops are azonal habitats, differing conspicuously from the surroundings. Therefore, it is not surprising, that several of their plant species are related to remote vegetation types. They either feature disjunct populations or their nearest relatives are located in distant areas.

(1) Relations to Pantepui - Inselbergs and "tepui" summits are subject to different geological and climatic conditions.
Phytogeographic relations between the two can only be stated for the southern inselberg district. Here, several genera can be found which have representatives in both altitudinal life zones at similar humid climatic conditions, e.g. Brewcaria, Decagonocarpus, Diacidia, Kunhardtia, and Navia.

(2) Relations to the Caribbean Region - Especially the flora of the northern inselberg district features distinct phytogeographic connections to the Caribbean region. Several typical elements of the Caribbean floristic province
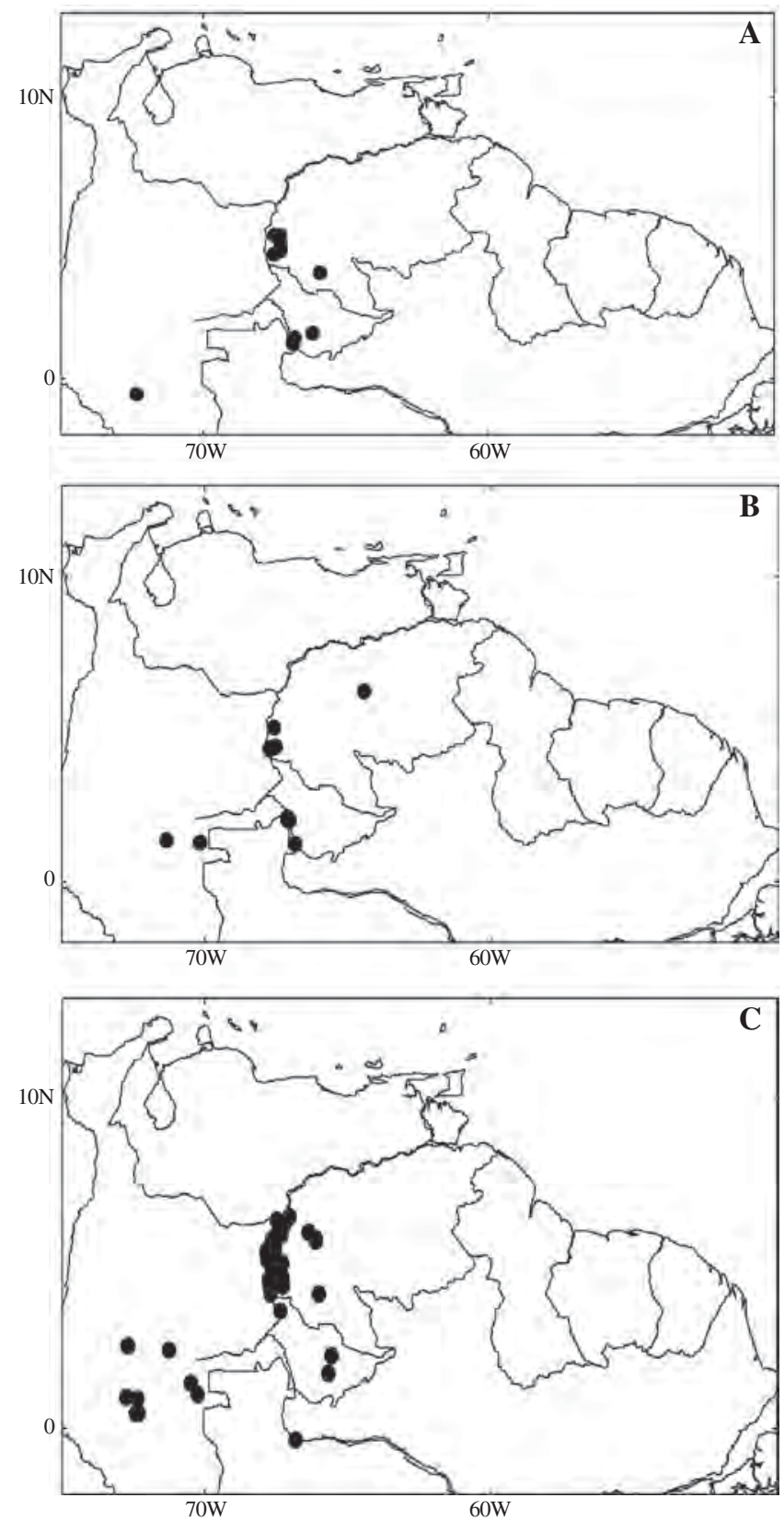

Figure 9. Distribution maps of shrub species, endemic mainly to the southern inselberg district. A. Decagonocarpus oppositifolius Spruce ex Engl. B. Diacidia galphimioides Griseb. C. Acanthella sprucei Hook. f. 
reach their southernmost limit of distribution on those inselbergs, species like Acanthocereus tetragonus (L.) Hummelinck, Pereskia guamacho F.A.C. Weber, Tillandsia schiedeana, etc. For various other taxa the populations on the northwestern inselbergs connect like stepping stones the disjunct populations of the xeric Caribbean coast with those of the semi-arid areas in the Rio BrancoRupununi region (Roraima territory of Brazil, and adjacent southern Guyana). These species are e.g. Bursera simaruba (L.) Sarg., B. tomentosa (Jacq.) Triana, Cyrtocarpa velutinifolia (Cowan) J.D. Mitch. \& Daly, Tabebuia ochracea (Cham.) Standl. subsp. heterotricha (A.DC.) A.H. Gentry. Other hints pointing to the Caribbean region can be obtained, regarding the next relatives (in brackets) of several inselberg-endemic species, such as Erythroxylum williamsii (E. spinescens A. Rich. group), Melocactus mazelianus Ríha (M. curvispinus Pfeiff. group) and Syagrus orinocensis (S. stenopetala Burret).

(3) Relations to the Brazilian Shield - The distribution ranges of some inselberg species even reveal connections to the Brazilian Shield. An evident example is given by Commiphora leptophloeos (Mart.) J.B. Gillett, a characteristic Burseraceae species of the Brazilian "caatinga" and of Bolivian inselbergs (Ibisch et al. 1995). Its scattered occurrence north of the Amazon is interpreted by Pennington et al. (2000) simply as a relict, occurring at low frequencies in the Amazonian rain forest. But it is important to know, that the occurrence of Commiphora leptophloeos north of the Amazon is confined exclusively to rocky outcrops, since it is not reported for any other vegetation type there (figure 10A). A similar amphi-equatorial pattern can be observed within the Sterculiaceae Helicteres heptandra L. This shrub is nearly exlusively known from the woody "caatingas" in northeastern Brazil (Cristóbal 2001, figure 10B). Outside of this area, it is only documented for a small region in the northern Bolívar State of Venezuela, where it grows in low dry forests on granitic outcrops. The genus Melocactus is another source for distribution patterns bridging the Amazon basin. Melocactus neryi K. Schum. (figure 10C) and M. smithii (Alexander) Buining are both endemic to granitic outcrops of the Guayana Shield, ranging from the Venezuelan state of Bolívar to Suriname, Guyana, and the Brazilian states of Roraima and Amazonas. According to Taylor (1991), the two species belong to the M. violaceus Pfeiff. group, which has its centre of diversity located in Eastern Brazil. The phytogeographic relation to the Brazilian Shield is strengthened by those inselberg-endemic species of Venezuelan Guayana, which have their nearest relatives in the Brazilian "caatinga", "cerrado" or "campo rupestre" vegetation. Examples (with relatives in brackets) are the recently described (Prata et al. 2007) new species of Bulbostylis medusae (B. sellowiana (Kunth) Palla), Cipura rupicola Goldblatt \& Henrich (C. xanthomelas Mart. ex Klatt), and Pseudobombax croizatii (P. campestre (Mart. \& Zucc.) A. Robyns).

\section{Conclusions}

The inselberg vegetation of the western Guayana Shield can be separated into two different phytogeographical units: a northern and a southern district. An overlap of these two units leads to a centre of diversity and endemism in the Átures area (sensu Steyermark 1979).

The northern and the southern inselberg districts differ from each other not only in their floristic composition, but also in their phytogeographical correlations. The southern district shows a clear connection with the "tepui" flora. Whereas the northern district is characterized by relations directed towards two remote areas of seasonally dry vegetation, the Caribbean region in Venezuela and Colombia and the "caatinga" and "cerrado" in northeastern and Central Brazil.

Especially during the dry glacial periods of the Quaternary, a floristic interchange across the equator took place (Prado \& Gibbs 1993). One postulated migration route is leading along the Andean dry valleys. Another route may have been created by a corridor of deciduous forests and savannas crossing the Amazon lowlands (Clapperton 1993, Daly \& Prance 1989). In this context, Guayanan inselbergs may play an important chorological role for the distribution of xerophytic taxa.

A converse model is proposed for gallery forests, which facilitate the migration of rain forest species from one refuge area to another passing regions with a dry climate (Oliveira Filho \& Ratter 1995). However, whereas gallery forests are offering continuous, dendritic migration routes, inselbergs represent at most largely discontinuous and scattered stepping stones, which are functionally like islands in the sea.

In our opinion, the hard data available for reconstructing consistent distribution processes of dry habitat taxa within the wider Amazon basin are still too scarce to allow the elaboration of general distribution models. However, the presence of several and significant taxa found in the Guayana Shield to the North and the Brazilian Shield to the South, give evidence of former exchange processes between the two regions.

Acknowledgements - The authors wish to acknowledge the "Studienstiftung des Deutschen Volkes" for major funding of the field work in Venezuela, and the organizers of the $55^{\text {th }}$ 

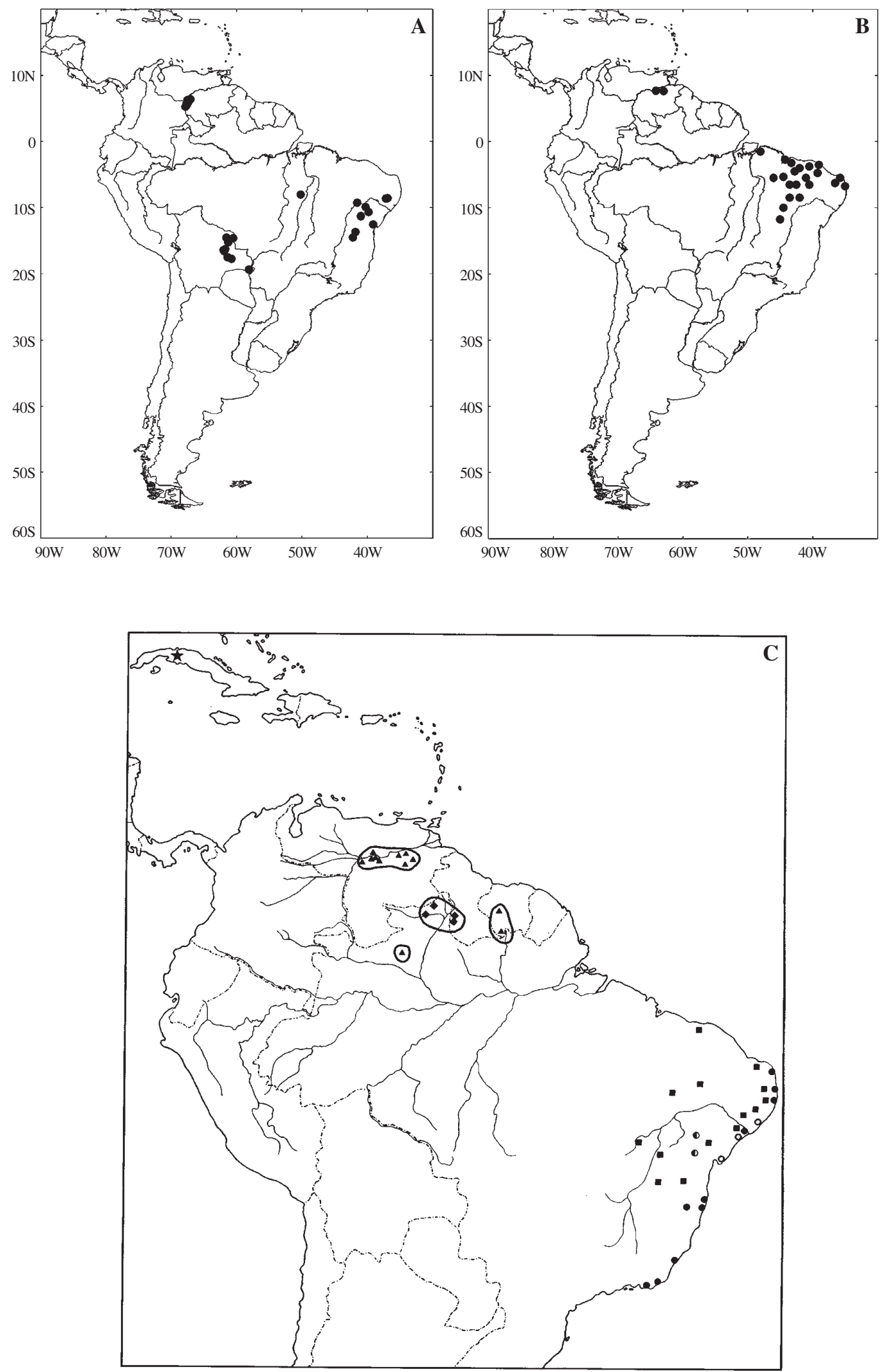

Figure 10. Examples for extra-regional distribution patterns. A. Commiphora leptophloeos (Mart.) J.B. Gillett. B. Helicteres heptandra L. (Cristóbal 2001, modified); C. Melocactus neryi K. Schum. (ム) and its relatives from the Violaceus-group (Taylor 1991): M. matanzanus León ( $\star$ ), M. smithii (Alex.) Buining ex G. Rowley ( $\bullet$ ), M. violaceus Pfeiff. (•), and M. zehntneri (Britton \& Rose) Lützelb. (ロ). 
Brazilian Botanical Congress in Viçosa (Minas Gerais) for sponsoring of the presentation, in particular to Fábio Scarano and Alexandre F. da Silva (in memoriam). We are grateful to Mrs. Jenny Wainwright-Klein for the careful reading of the manuscript.

\section{References}

BERRY, P.E., HUBER, O. \& HOLST, B.K. 1995. Floristic analysis and phytogeography. In Flora of the Venezuelan Guayana, v. 1, Introduction (J.A. Steyermark, P.E. Berry \& B.K. Holst, eds.). Missouri Botanical Garden / Timber Press, St. Louis / Portland, p.161-191.

BLANCANEAUX, P. \& POUYLLAU, M. 1977. Formes d'altération pseudokarstiques en relation avec la géomorphologie des granites précambriens du type Rapakivi dans le territoire fédéral de l'Amazone, Vénézuela. Cahiers Orstom, Série Pédologie 15:131-142.

BOOM, B.M. 1990. Flora and vegetation of the GuayanaLlanos Ecotone in Estado Bolivar, Venezuela. Memoirs of the New York Botanical Garden 64:254-278.

BÜDEL, B., LÜTTGE, U., STELZER, R., HUBER, O. \& MEDINA, E. 1994. Cyanobacteria of rocks and soils of the Orinoco Lowlands and the Guayana Uplands, Venezuela. Botanica Acta 107:422-431.

CLAPPERTON, C.M. 1993. Nature of environmental changes in South America at the Last Glacial Maximum. Palaeogeography, Palaeoclimatology, Palaeoecology 101:189-208.

CRISTÓBAL, C.L. 2001. Taxonomía del género Helicteres (Sterculiaceae); revisión de las especies Americanas. Bonplandia 11:1-206.

DALY, D.C. \& PRANCE, G.T. 1989. Brazilian Amazon. In Floristic Inventory of Tropical Countries (D.G. Campbell \& H.D. Hammond, eds.). New York Botanical Garden, New York, p.401-426.

DE GRANVILLE, J.-J. 1991. Remarks on the montane flora and vegetation types of the Guianas. Willdenowia 21: 201-213.

GRÖGER, A. 1994. Análisis preliminar de la flórula y vegetación del Monumento Natural "Piedra La Tortuga", Estado Amazonas, Venezuela. Acta Botanica Venezuelica 17:128-153.

GRÖGER, A. 1995. Die Vegetation der Granit-Inselberge Südvenezuelas: Ökologische und biogeographische Untersuchungen. Ph.D. thesis, Botanical Institute, University of Bonn, Bonn.

GRÖGER, A. 2000. Flora and vegetation of inselbergs of Venezuelan Guayana. In Inselbergs - biotic diversity of isolated rock outcrops in tropical and temperate regions (S. Porembski \& W. Barthlott, eds.). Springer, Heidelberg, p.291-314.

GRÖGER, A. \& BARTHLOTT, W. 1996. Biogeography and diversity of the inselberg (laja) vegetation of southern Venezuela. Biodiversity Letters 3:165-179.
GRÖGER, A. \& RENNER, S. 1997. Leaf anatomy and ecology of the Guayana endemics Acanthella sprucei and A. pulchra (Melastomataceae). BioLlania 6:369-374.

HUBER, O. 1994. Recent advances in the phytogeography of the Guayana region, South America. Mémoires de la Société de Biogéographie ( $3^{\text {th }}$ Série) 4:53-63.

HUBER, O. 1995a. Geographical and physical features. In Flora of the Venezuelan Guayana, v.1, Introduction (J.A. Steyermark, P.E. Berry \& B.K. Holst, eds.). Missouri Botanical Garden / Timber Press, St. Louis / Portland, p.1-61.

HUBER, O. 1995b. Vegetation. In Flora of the Venezuelan Guayana, v.1, Introduction (J.A. Steyermark, P.E. Berry \& B.K. Holst, eds.). Missouri Botanical Garden / Timber Press, St. Louis / Portland, p.97-160.

HUBER, O. \& FOSTER, M. (eds.) 2003. Conservation priorities for the Guayana Shield: 2002 Consensus. Conservation International - CABS, Guiana Shield Initiative, UNDP, IUCN, Washington DC.

HUMBOLDT, A. VON. 1819. Relation historique du Voyage aus regions équinoxiales du Nouveau Continent, ait en 1799-1904 par A. de Humboldt et A. Bonpland. Maze, Paris

IBISCH, P.L., RAUER, G., RUDOLPH, D. \& BARTHLOTT, W. 1995. Floristic, biogeographical, and vegetational aspects of Pre-Cambrian rock outcrops (inselbergs) in eastern Bolivia. Flora 190:299-314.

MAGUIRE, B. 1979. Guayana, region of the Roraima sandstone formation. In Tropical Botany (K. Larsen \& L.B. Holm-Nielsen, eds.). Academic Press, London, p.223-238.

MENDOZA, V. 1977. Evolución tectónica del Escudo de Guayana. Boletín de Geología. Publicación Especial 7:2237-2270.

OLIVEIRA FILHO, A.T. \& RATTER, J.A. 1995. A study of the origin of central Brazilian forests by the analysis of plant species distribution patterns. Edinburgh Journal of Botany 52:141-194.

PENNINGTON, R.T., PRADO, D.E. \& PENDRY, C.A. 2000. Neotropical seasonally dry forests and Quaternary vegetation changes. Journal of Biogeography 27:261273.

PRADO, D.E. \& GIBBS, P.E. 1993. Patterns of species distributions in the dry seasonal forests of South America. Annals of the Missouri Botanical Garden 80:902-927.

PRATA, A.P., CAMELBEKE, K., REYNDERS, M., FEDÓN, I.C., GOETGHEBEUR, P. \& HUBER, O. 2007. Bulbostylis medusae (Cyperaceae), a new species from Venezuela. Novon 17:67-71.

STEYERMARK, J.A. 1979. Plant refuge and dispersal centers in Venezuela: their relict and endemic element. In Tropical Botany (K. Larsen \& L.B. Holm-Nielsen, eds.). Academic Press, London, p.185-221.

TAYLOR, N. 1991. The genus Melocactus (Cactaceae) in Central and South America. Bradleya 9:1-80. 